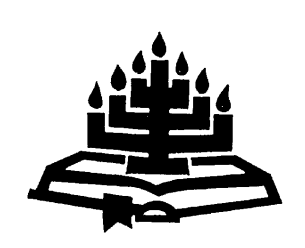

\title{
Benaderings tot die interpretasie van die wonderverhale in Markus 8-10
}

\author{
G.J. van Wyk \& F.P. Viljoen
}

Skool vir Bybelwetenskappe \& Antieke Tale

Potchefstroomkampus

Noordwes-Universiteit

POTCHEFSTROOM

E-pos: gerrievanwyk@gksa.co.za

Francois.Viljoen@nwu.ac.za

\begin{abstract}
Approaches to the interpretation of miracle stories in Mark 8-10

Research on the miracle stories in Mark 8-10 and their role in this Gospel is discussed. The mythological, religious-historical, form-historical, Biblical-theological, redaction-historical, sociological, literary-critical, the research of Van der Loos and Brown, salvation-historical and revelation-historical research are discussed. Research shows that the kingdom of God, a paradoxal Christology and discipleship play an important role in the miracles and miracle stories in the Gospel of Mark. Miracles form an integral part of the gospel and ministry of Jesus. They serve to support the teaching of Jesus.
\end{abstract}

\section{Opsomming}

\section{Benaderings tot die interpretasie van die wonderverhale in Markus 8-10}

Navorsing oor die wonderverhale met verwysing na Markus 810 en die rol daarvan in hierdie Evangelie word bespreek. Die mitologiese, godsdienshistoriese en vormhistoriese benaderings, 'n Bybels-teologiese benadering, die redaksiehistoriese, die sosiologiese, die literêrkritiese, die oorsigtelike benadering van Van der Loos en Brown, die Heilshistoriese en die Openbaringshistoriese benaderings word bespreek. Uit die verskillende benaderings blyk dat die koninkryk van God, 'n paradoksale Christologie sowel as dissipelskap 'n belangrike plek in die wonderwerke in die Markusevangelie inneem. Die wonderwerke vorm 'n inherente deel van die Evangelie en die bedie- 
ning van Jesus. Hulle dien daartoe om die onderrig van Jesus te ondersteun.

\section{Inleiding}

Navorsingsresultate word wesenlik beïnvloed deur die metodes van ondersoek wat gevolg word. In hierdie artikel word 'n oorsig gebied van die stand van navorsing oor die interpretasie van wonderverhale ${ }^{1}$ in die Markusevangelie. Ter toeligting van hierdie verskeidenheid word wonderverhale van Markus 8-10 as voorbeelde gebruik: die genesing van twee blindes onderskeidelik (Mark. 8:22-26; 10:4652), die verheerliking op die berg (Mark. 9:2-9) en 'n demoonuitdrywing (Mark. 9:14-29). Van die mees algemene navorsingsmetodes om hierdie wonderverhale te interpreteer, word oorsigtelik ondersoek om aan te toon watter effek dit op die interpretasie van hierdie verhale het en om die rol van die wonderverhale in hierdie Evangelie te bepaal.

\section{Mitologiese, godsdienshistoriese en vormhistoriese benadering}

Strauss $(1973: 52,86,160)$ se siening van die wonderverhale het in later jare 'n groot invloed op navorsing uitgeoefen. Hy beskou die grootste deel van die Evangelie as onhistoriese mites. Hierdie mitologiese benadering laat 'n minimale historiese raamwerk vir die lewe en wonderwerke van Jesus. Die godsdienshistoriese en vormhistoriese benaderings van Bultmann² (1979:246) en Dibelius (1934:70 e.v.) beklemtoon dat die wonderverhale van die Evangelies ten opsigte van vorm, inhoud en die motief in noue samehang met die wonderverhale van die Joodse en Hellenistiese wêreld van destyds beskou moet word. Wonderverhale sou 'n nie-Christelike oorsprong hê (Dibelius, 1934:100). Ook Bousset (1970:100) het die historiese betroubaarheid van die wonderverhale van Jesus bevraagteken. Hy meen dat allerlei wonderverhale van ander wonder-

1 Sommige navorsers meen dat wonderverhale nie oorspronklik deel van die Evangelies uitgemaak het nie (Strauss, 1973:52, 86, 160; Bousset, 1970:100). Ander navorsers meen weer dat wonderverhale wel 'n integrale deel van die Evangelies uitmaak. Ongeveer 30\% van die Markusevangelie handel oor Jesus se wonders (Richardson, 1948:36; Meye,1978:2; Flynn,1990:7). Dit dui daarop dat Markus die rol van wonders belangrik ag in die aanbieding van sy Evangelie.

2 Bultmann (1979:246) konkludeer dat die wonderverhale in die Markusevangelie "arise in the same atmosphere as the Jewish and Hellenistic miracle-stories". 
doeners van destyds aan Jesus toegedig is. Die vroegste tradisies oor Jesus se lewe sou relatief vry wees van die wonderbaarlike. Die lydensverhale wat min wonderwerke vermeld, sou kenmerkend wees van die vroegste tradisies oor Jesus, terwyl die wonderverhale kenmerkend van die latere tradisies sou wees (Bousset, 1970:98).

Die mitologiese interpretasie van die wonderwerke is deur Bultmann (1965:156) verder uitgewerk. Hy voer aan dat 'n konsekwente historiese ondersoek van Jesus die Evangelie van sy waarde stroop. Die opstanding van Christus sou deel uitmaak van hierdie mitologiese wêreldbeeld. Die fisiese opstanding van Jesus word daarom nie histories beskou nie (vgl. Snyman, 1977:236 e.v.; Van Wyk, 2002:609). Bultmann $(1961: 221,224)$ erken net een wonder en dit is die openbaring van die genade van God wat die goddelose vergewe.

Dit bly ' $n$ vraag waarom Bultmann Jesus se prediking en onderrig wil aanvaar, maar die wonderwerke en die opstanding wat 'n inherente deel van die Evangelie uitmaak, nie aanvaar nie. Deur dit te doen, stroop Bultmann die Evangelie van 'n inherente komponent (vgl. Coetzee, 1970:116; Latourelle, 1988:29; Ridderbos, 1968:79, 85).

\section{3. 'n Bybelse teologiebenadering}

Teenoor die vormkritiek, wat Richardson (1948:20) 'n cul-de-sac noem en die mitologiese benadering van Bultmann, kom Richardson met sy Bybelse teologiebenadering. Hy voer aan "disregard of the biblical theology leads inevitably to the attempt to explain away the power of God as it has been revealed in history" (Richardson, 1948: 18). Die wonderverhale verkondig dat God se koninkryk aangebreek het (Richardson, 1948:44). Jesus gebruik wonders as profetiese en dikwels simboliese dade wat sy onderrig toelig. Wonders kan as "enacted parables" (Richardson, 1948:51) beskou word. Wonderverhale het 'n missionêre funksie vanweë die verband tussen genesingswonders en verlossing (Richardson, 1948:61).

Richardson se benadering hou rekening met die feit dat wonderverhale 'n prominente en integrale deel van die Evangelies vorm. Hy toon oortuigend aan dat die wonderverhale die onderrig van Jesus in die evangelie toelig.

\section{Redaksiehistoriese benadering}

In die vormkritiek is op kleiner eenhede in die Evangelies gekonsentreer waarvolgens die skrywers tradisies versamel het. Die redaksiekritiek het op die redaksie van die Evangelies as 'n geheel, 
die teologiese bedoeling van die afsonderlike evangeliste, asook op die finale fase van die samestelling van die Evangelies gefokus (Smalley, 1979:181; Vorster, 1982:104 e.v., 107). In die redaksiekritiek is die wonderverhale in verhouding tot Jesus se onderrig as woordverkondiging bespreek.

Meye (1968:87) laat die klem op Jesus as Goddelike leraar val. Jesus se prediking, gelykenisse, dade en sy bediening dra alles daartoe by om die misterie van die koninkryk van God bekend te stel. Daar bestaan 'n noue samehang tussen Jesus se woord- en daadverkondiging (Meye, 1978:3 e.v.). Die Ou Testament voorsien die literêre en godsdienstige horisonne vir die verstaan van die wonderwerke van Jesus asook van Jesus self. Volgens Meye (1978:5) bied Psalm 107 die horison, nie bloot die agtergrond nie, vir die interpretering van die wonderverhale in die Markusevangelie. Die magtige dade van Jesus bied beslissende manifestasie van die Koninkryk van God (Mark. 1:14-15), waarin die krag van die Gees van God na vore kom (Mark. 1:9-13 en 3:22-26). Meye (1978:7 e.v.) wys op vier belangrike ooreenkomste tussen Psalm 107 en Markus 4:35-8:263 waarin die motiewe van verlossing, goddelike medelye asook die motief van verstaan 'n rol speel.

Schweizer $(1995: 67,69)$ meen dat Jesus se wonderwerke ondergeskik is aan sy onderrig. Die eerste eksorsismewonder lei tot die vraag: "Wat gaan hier aan? Dit is 'n nuwe leer en dit kom met gesag!" (Mark. 1:27). Schweizer toon aan dat nie net sommiges se fisiese blindheid nie, maar al die mense se geestelike blindheid prominent in die Markusevangelie funksioneer. In die wonderverhale gaan dit om die wonder van Goddelike openbaring. Ten spyte van die geestelike blindheid van die Fariseërs, die Jode en die dissipels, vind die wonder van dissipelskap plaas. So bereik God se openbaring sy doel. Geloof kom tot stand en hierdie boodskap word geleef en uitgedra (Schweizer, 1995:80).

Kertelge (1995:111) beklemtoon dat die wonderverhale deel vorm van Jesus se verkondiging. God se verlossende optrede word in die besonder deur Jesus se dood en opstanding verkondig (Kertelge,

3 (1) Verlossing van honger en dors in die wildernis: Psalm 107:4-9 en Markus 6:30-44; 8:1-10; 14-21; (2) Verlossing van gevangenskap: Psalm 107:10-16 en Markus 5:1-20; 6:13; 7:24-30; (3) Verlossing van siekte: Psalm 107:17-22 en Markus 5:21-6:5; 13:53-56; 7:31-37; 8:22-26; (4) Verlossing van die storm op see: Psalm 107:23-32 en Markus 4:35-41; 6:45-52. Hierdie vier motiewe figureer ook elders in die Ou Testament (vgl. Watts, 1997:170). 
1995:115, 117). Die geheimenis- en openbaringsmotief figureer dwarsdeur die Markusevangelie. Jesus is in sy prediking en wonderwerke, in sy lyde en sterwe, die paradoksale, verborge Messias, Seun van die mens en Seun van God wat deur geen mens, selfs nie eers sy dissipels behoorlik verstaan word nie (Kertelge, 1995:114 e.v., 117). Die dissipels word geroep om die lydende Jesus na te volg - Jesus wat sy lewe afgelê het, maar ook opgestaan het. Die opstanding is 'n belangrike openbaringsmoment waarop die hele Markusevangelie afstuur. Dit is slegs vanuit die perspektief van die opstanding wat Jesus werklik verstaan word. Deur sy opstanding is Jesus as Seun van God geopenbaar (Kertelge, 1995:120 e.v.).

Sedert die sestiger- en sewentigerjare van die vorige eeu is gepoog om die Messiasgeheim 4 te interpreteer. Die gevolg is dikwels dat die wonderwerke van Jesus ondergeskik aan sy verkondiging gestel word. Weeden (1968:146; 1971:163) is van mening dat Markus met dié motief 'n valse $\Theta \in \hat{\imath} o s$ à $\nu$ ́́ $\rho$-Christologie wou korrigeer. Perrin (1995:131) is van mening dat Markus met 'n teologie van die kruis (wat in die tweede deel van Markus voorkom), 'n valse

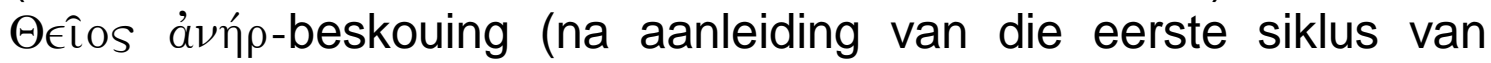
Jesus se wonders) wou bestry. Duling en Perrin (1994:305) beklemtoon die belangrike plek van Markus 8:27-10:45, asook die genesing van twee blindes in Markus 8:22-26 en Markus 10:46-52 onderskeidelik in die struktuur van die Markusevangelie. Hulle tipeer Markus 8:27-10:45 as Christologie en dissipelskap ook in die lig van die lydensgebeure. Markus stel hom inderdaad ten doel om Jesus as leraar te verkondig. Hy gebruik wonderverhale om hierdie doel te bereik. Die verhouding tussen geloof en wonderwerke is daarom belangrik. Sonder God se openbaring oor en deur Jesus wat preek, leer, wonders doen, sterf en opstaan, kan dissipelskap en die implikasies daarvan moeilik verstaan word.

Best (1981:134 e.v.) bespreek die twee genesingswonders van blindes (Mark. 8:22-26 en 10:46-52) saam en lei 'n simboliese betekenis uit albei genesingswonders af. Die eerste wonder (Mark. 8:22-

Wrede (1963:80) het met Das Messiasgeheimnis in die Markusevangelie bekendheid verwerf. 'n Verband is deur Wrede gelê tussen die Messias en die geheimenismotief in die Markusevangelie. Vir Wrede hou die geheimenismotief verband met die volgende sake: dat Jesus die Messias of die Seun van God is; dat Jesus se wonderwerke aandui dat Hy die Messias is; dat Jesus se hele onderrig vir die menigtes verborge bly; en dat die betekenis van die gelykenisse slegs vir Jesus se dissipels ontsluit word (Wrede, 1963:80). Markusnavorsers het sedertdien verskeie interpretasies van die geheimenismotief in die Markusevangelie voorgestel (vgl. Tuckett, 1983; Kertelge, 1995:115). 
26) sluit die wonderwerkedeel van Markus (4:35-8:26) af en lei die dissipelskapsdeel (8:27-10:52) in. Die tweede genesing van 'n blinde (Mark. 10:46-52) verbind die dissipelskapsdeel met die verhaal van die kruisiging. Ten opsigte van Markus 8:22-26 meen Best (1981:134) dat die klem nie op die genesing val nie, maar op die simboliese betekenis, die herstel van die sig van die dissipels en wel in twee stadia soos in die genesing van die blinde man. Alhoewel die simboliese betekenis van die wonders nie betwis word nie, is dit 'n vraag of die wonders so maklik versimboliseer kan word asof dit slegs die dissipelskapstema dien en dit die hooffunksie van die wonderverhaal sou wees.

Die waarde van die redaksiehistoriese benadering is dat navorsers op die teologiese bedoeling van die afsonderlike evangeliste en die finale fase van die samestelling van die Evangelies gefokus het. Hulle toon aan dat die wonderverhale op 'n bepaade manier bydra tot die uitdrukking van die boodskap van die onderskeie evangeliste. Alhoewel sommige redaksiehistoriese navorsers die historisiteit van Jesus se wonderwerke bevraagteken, toon hulle aan dat die wonderverhale in die Markusevangelie die boodskap van Jesus ondersteun.

\section{Sosiologiese benaderings}

Theissen (1983:208) wys op die sosiale en historiese konteks van die wonderwerke, asook op die verband tussen Jesus se wonders, sy onderrig en dissipelskap. Die verband tussen wonderwerke en Christologie figureer dwarsdeur die Markusevangelie. Vanaf Markus 8:27 speel Jesus se dood 'n belangrike rol. Die paradoks van die Evangelie blyk uit die wonderwerke enersyds en Jesus se lyde en sterwe andersyds. Die simboliese karakter van die wonderwerke roep die lesers tot bekering en geloof op. Die wonderverhale reflekteer die boodskap van die evangelie (Theissen, 1983:299).

Die wonderverhale in Markus is ten nouste aan die verkondiging van die evangelie van die koninkryk verbind. Die wonderwerke kondig 'n nuwe era aan waarin die koninkryk van God naby is. As paraboliese dade dra die wonderwerke van Jesus in 'n gedramatiseerde vorm essensiële Christologiese onderrig oor (Uth, 1991:ii, 213 e.v.). In die wonderwerke word die koms van die koninkryk deur Jesus aangekondig vir armes, veragtes, sondaars en diegene wat ly. Wonderwerke en verlossing is onskeibaar. Jesus het gekom om moontlik te maak wat vir mense onmoontlik is (Uth, 1991:90 e.v.). 
Kee (1977:ix) ontleed die wonderwerke in hulle oorspronklike sosiaal-historiese konteks. Die verhouding tussen die Ou en Nuwe Testament is van wesenlike belang vir die Christologie, dissipelskap en die wonderwerke (Kee, 1988:9). In die Ou Testament beklee wonderwerke 'n belangrike plek (vgl. Ps. 78:43; 105:27; 107:24). Jahweh word dikwels as Geneser van sy afvallige en sondige verbondsvolk geopenbaar. In Jesaja 53:4-6 word die genesing van God se volk verbind aan die Kneg van die Jahweh wat sou ly, in sy volk se plek verwerp word en hulle so sou genees. In aansluiting by hierdie en ander profesieë (bv. Jes. 26:16-21 en Dan. 4:2-3; 6:26-27) word die wonderwerke van Jesus in die sinoptiese Evangelies weergegee. Die twee genesingswonders van blindes vervul 'n strategiese rol in Markus 8-10 en hou verband met die geestelike blindheid van sy dissipels tot met die kruisiging (Kee, 1977:23).

Die sosiologiese benadering voeg waarde tot die ondersoek van wonderverhale toe deur die sosiale konteks van die wonders te ontleed en die impak van die destydse wonders te beskryf. Uit hierdie ondersoeke word die funksie van die wonderverhale in die Evangelies toegelig en bevestig.

\section{Literêr-kritiese of narratiewe benadering}

Die literêr-kritiese of narratiewe benadering benader die Evangelies nie bloot as kerugma of as geskiedenis nie, maar as vertellings. Die skrywer tree as verteller van die verhaal op. As sender dra hy sy perspektief aan die leser as ontvanger oor. In die vertellersperspektiefanalise neem historiese vrae en "historisiteit" dienooreenkomstig 'n genuanseerde rol in (Bal, 1985:27; Vledder, 1984:108). Die historiese gegewens wat in die teks na vore kom, dien as agtergrondgegewens by die vertelling. Dit bied bykomende inligting tot die beter verstaan van die karakters, intrige (plot), ${ }^{5}$ ruimte en tyd van die narratief (Vorster, 1980:126).

Engelbrecht (1983:118) toon aan dat Christologie en dissipelskap 'n sentrale plek in die wondervertellings in die Markusevangelie beklee. Hy identifiseer 'n paradoksale Christologie waarin twee lyne oor Jesus, naamlik die verheerlikte Wonderdoener en die lydende

5 Onder intrige (plot) word die plan of struktuur van die gebeure of handelinge in 'n vertelling verstaan, wat sodanig gerangskik is dat die verhaal ontvou. In die ontwikkeling van die intrige word ' $n$ bepaalde verwagting by die leser gekweek oor hoe die verhaal sal verloop of afloop (Vledder, 1984:102; Vorster, 1980: 126). 
Seun van die mens wat sterf en opstaan, mekaar ontmoet (vgl. Engelbrecht, 1983:44, 50). Die dissipels se optrede is ook paradoksaal. Hulle is so bevoorreg om geroep te word en saam met Jesus te wees, maar hulle verstaan nie die volle omvang van hierdie gebeure nie. Die leser word by die verhaal betrek om te deel in die verteller se teleurstelling met die gebrek aan begrip van die dissipels (Engelbrecht, 1983:47 e.v.; 53).

Die belangrike funksie van die minor-6karakters in die Markusevangelie is deur Malbon, Williams en Bolt aangetoon. Volgens Malbon $(1994: 60,65)$ vergestalt die geringer karakters geloof in Jesus se genesende krag en gesag as verkondiger van die koninkryk van God. Hierdie karakters se verhale van geloof en genesing is essensieël vir die Christologie en dissipelskap in die Markusevangelie. Malbon aanvaar die simboliese betekenis van die twee verhale, waarin twee geringer karakters (twee blindes), asook die genesing van die epileptiese (besete) seun in Markus 8:22-10:52 voorkom. Die dissipels asook sommige van die geringer karakters word as feilbare volgelinge in die Markusevangelie voorgestel. Die ryk jong man wat nie kans sien om Jesus te volg nie en Bartimeus wat Jesus wel volg, word met mekaar gekontrasteer. In die sorgvuldig gestruktureerde sentrale gedeelte van Markus, naamlik Markus 8:22-10:52 vervul die geringer karakters 'n indrukwekkende funksie vir die implisiete hoorders (Malbon,1994:66). Die persone om Jesus reageer op een van drie wyses op Jesus: óf as vyande, óf as feilbare volgelinge, óf as voorbeelde. Die dissipels is feilbare volgelinge van Jesus, terwyl die meeste van die geringer karakters as voorbeelde vir navolging voorgehou word (Malbon, 1994:71).

Williams (1996:332) gee ook aandag aan dissipelskap en die sogenaamde geringer karakters in die Markusevangelie. Jesus word in Markus 8:27-10:45 getipeer as dié voorbeeld of paradigma vir sy volgelinge. Jesus moes baie ly en sterf en net so moet sy volgelinge hulleself verloën en hulle lewens ter wille van Jesus verloor (Williams, 1996:340). Die Christologie en die wonderwerke in Markus 8:27-10:45 hou verband met die belangrike saak van dissipelskap in die Markusevangelie. Die voorstelling van die geringer karakters in die Markusevangelie is sowel 'n roeping as ' $n$ waarskuwing. Die uitnodiging om Jesus wat leer, preek en wonderwerke doen as Verlosser te volg, is oop vir enigeen wat glo. Dit sluit egter selfverloëning, opoffering, gewillige en nederige diens in.

6 Minder prominente, hierna geringer karakters genoem. 
Die dissipels van Jesus word in die Markusevangelie nie tot die Twaalf beperk nie. Bolt (2003) bespreek dertien geringer karakters in die Markusevangelie. Drie van hierdie karakters kom in Markus 810 voor. Die genesing van die twee blindes (Mark. 8:22-26; 10:4652) sinspeel in die Markusevangelie op sien as 'n metafoor vir insig (Bolt, 2003:210, 216, 238). Die eerste blinde man word genees as die klimaks van 'n lang gedeelte waarin die temas van hoor en sien herhaaldelik op die agenda is as metafore vir glo en insig in die persoon van Jesus. Hierdie genesingswonder dien as 'n konkrete illustrasie van Jesus se vermoë om die oë van blindes te open, nie net vir diegene wat fisies blind is nie, maar ook vir diegene wat metafories blind is. Jesus se mag word beklemtoon in die verhaal van die genesing van die besete seun (Mark. 9:14-27). Bolt (2003: 228) tipeer die genesing van die besete seun in opstandingsterme, naamlik opwekking uit die dood.

In sy narratiewe benadering bespreek Marshall (1989:57 e.v.) die prominente plek van wonderwerke in die roeping tot geloof. Wonderwerke vervul 'n belangrike didaktiese funksie. Die wonderwerke is vir Jesus se dade dieselfde wat die gelykenisse vir Jesus se onderrig is, naamlik boodskappe of raaisels wat om interpretasie vra. Wonderwerke funksioneer as daadgelykenisse (Marshall, 1989:61). Die wonderwerke is nie geïsoleerde verskynsels nie, maar tekens van die teenwoordigheid van die koninkryk van God (Marshall, 1989:62). In die persoon van Jesus openbaar God sy mag.

Broadhead (1992:145) toon aan dat die wonderwerke op die identiteit en missie van Jesus en dissipelskap gerig is. Jesus genees nie net twee blindes onderskeidelik nie (Mark. 8:22 e.v. en 10:46 e.v.), maar ook die geestelike blindheid van sy volgelinge. Wonders bevestig die gesagvolle verkondiging van Jesus en dien die missionêre uitreik na die heidene. Geeneen van die wonderwerke neem die geestelike blindheid van die dissipels weg nie. Dissipelskap word uiteindelik die wonderwerk wat al die wonderwerke oortref (Broadhead, 1992:166).

Dit is duidelik dat die narratiewe benadering nie op die historisiteit van die wonderwerke fokus nie, maar op die funksie wat die verhale in die vertelling vervul. Markus gee sy perspektief op die wonders weer om daardeur sy siening oor die navolging van Christus aan sy hoorders oor te dra. Hierdie benadering erken dat wonderverhale funksioneel aangewend word as deel van die Evangelie. 


\section{Navorsing van Van der Loos en Brown}

Van der Loos $(1968: 179,237)$ voer aan dat die woorde en dade van Jesus in die Markusevangelie 'n eenheid vorm. Deur die wonders van Jesus word die mag van God geopenbaar. Drie aspekte van Jesus se optrede as Wonderwerker, naamlik die Messias, die Profeet, die Priester kan onderskei word (Van der Loos, 1968:235 e.v.; 240 e.v.). Die wonderwerke is 'n vorm van Goddelike openbaring wat alleen in die geloof werklik verstaan kan word (Van der Loos, 1968: 46). Die genesing van die besete seun (Mark. 9:14-29) openbaar Jesus se almag teenoor die onvermoë van sy dissipels. Die genesing van die besete seun demonstreer nie net hoe groot Jesus Christus se mag is nie, maar ook dit wat geloof tot stand kan bring. Sonder geloof en gebed bly Jesus se volgelinge magteloos. Die tyd van voller openbaring breek vir die dissipels aan wanneer Jesus sterf en uit die dood opstaan (Van der Loos, 1968:401, 418). Die genesing van die blinde Bartimeus (Mark. 10:46-52) hou verband met Jesus wat op pad is na Jerusalem om te ly en te sterf.

Volgens Brown (1984:vii) is die Christendom ondenkbaar sonder Jesus wat wonderwerke verrig. Sy onderrig is net so ondenkbaar sonder sy tekens as wat sy tekens ondenkbaar is sonder sy onderrig. Die wonderwerke bied die sleutel tot die verstaan van Jesus en waarom die Joodse owerhede destyds vir Jesus wou ombring (Brown, 1984:vii). Die profesie van Johannes die Doper aangaande Jesus dien as agtergrond waarteen die wonderverhale in die Evangelies gelees moet word. 7 Die wonderwerke hou verband met die menswording van die ewige Seun van God en die openbaring van die drie-enige God. In die wonderwerke gaan dit om openbaring. In die sinoptiese Evangelies is die wonderwerke tekens van die vervulling van die messiaanse profesie (Brown, 1984:287). Met hierdie wondertekens eis God insig, geloof en gehoorsaamheid.

Van der Loos en Brown toon oortuigend die onlosmaaklike band tussen die wonderverhale en onderrig van Jesus aan. Die wonderverhale toon aan dat Jesus die Seun van God is, met die gevolg dat Hy met Goddelike gesag kan onderrig en optree.

7 Die wonderwerke van Jesus word in die geheelkonteks van die aktiwiteit van die Gees van God in die Markusevangelie verduidelik (Brown, 1984:305). 


\section{Die heilshistoriese benadering van Ridderbos}

In sy heilshistoriese benadering noem Ridderbos (1972:16) die koms van die koninkryk van God die sentrale tema van Jesus se prediking wat verlede, hede en toekoms omspan. In Jesus se koms, Persoon en optrede in woord en daad as die deur-God-gestuurde Messias, het die koninkryk sigbaar en teenwoordig geword (Ridderbos, 1972:22, 88, 90). Jesus se optrede, veral sy woord- en daadverkondiging is openbaring van God en sy koninkryk. Uit Jesus se optrede, sy prediking en wonderwerke blyk die "reeds" en die "nog nie ten volle" van die koninkryk van God (Ridderbos, 1972:60). In Jesus se wonders lê die reeds, die koms van die koninkryk van God opgesluit. Jesus se woorde en dade as verkondiging van die koninkryk vorm 'n eenheid en is messiaanse heilsweldade wat 'n eskatologiese karakter dra. In die wonders gaan dit om die verheerliking van God. Dit stel, net soos die prediking van Jesus, mense voor 'n keuse: vir of teen Jesus as Oorwinnaar oor die bose en die Draer van, of Doper met die Heilige Gees. Dit gaan in Jesus se wonderwerke nie oor die wonder as sodanig nie, maar oor die verlossing wat daardeur geopenbaar word (Ridderbos, 1972:78). Die wonders is insidenteel en voorlopig en wys vooruit na die koninkryk wat finaal sal kom.

Ridderbos toon aan dat die wonders nie 'n doel op sigself is nie, maar ' $n$ wesenlike middel tot ' $n$ doel. Dit bly ondergeskik aan die prediking van die evangelie. Die wonderwerke het slegs betekenis in so verre dit gepaard gaan met geloof in die prediking van die evangelie en in Jesus as die Christus.

\section{Openbaringshistoriese benadering}

Die openbaringshistoriese benadering neem as vertrekpunt dat God Homself in die geskiedenis geopenbaar het. Openbaring is op werklike gebeure gebaseer. Die gebeure het egter 'n boodskap, want dit is God wat Hom in die historiese gebeure of feite openbaar (Helberg, 1976a:6; Van der Walt, 2006:21). Die historiese gebeure hou onderling verband met mekaar en vorm 'n openbaringshistoriese lyn. Die historiese element is nie die oorheersende nie, maar God se openbaring deur die Goddelike woord staan voorop (Helberg, 1976b:24; 1988:2 e.v.).

In hulle openbaringshistoriese benadering beklemtoon Snyman en Floor (1969:37; 1977:198, 201) die weg van die koninkryk. In Jesus se woord- en daadverkondiging, maar ook in sy Persoon tree die evangelie van die koninkryk van God aan die lig (Floor, 1981:1; Van 
der Walt, 1962:52 e.v.). Die koms en openbaring van die koninkryk van God hou ten nouste verband met die belydenis dat Jesus die Christus, die Seun van God is (Snyman \& Floor, 1977:205). Die koninkryk openbaar 'n paradoksale karakter. Dit kom langs die weg van vernedering en verhoging. Jesus se woord- en daadverkondiging moet in noue samehang met sy lyde en sterwe enersyds en sy opstanding en toekomstige heerlikheid verstaan word. In die wonderverhale word aangesluit by die Ou Testament. Die Ou Testament (bv. Jes. 2:1-3; 42:20-21; 35:3-6; 43) het geprofeteer dat die Verlosser wonderwerke sou doen. Jesus se wonderwerke moet dus in aansluiting by die Ou Testament verstaan word.

Van der Walt (2006:194) wys daarop dat die wonders 'n wesenlike en integrale deel van die Evangelies uitmaak en dat dit kenmerkend van die messiaanse vrederyk sou wees. As historiese gebeurtenisse wil die wonderwerke 'n boodskap oordra. Jesus vertel gelykenisse, maar Hy doen ook wonderwerke. Dit is daadpreke of daadverkondiging. Dit is gelykenisse in aksie. Van der Walt (2006:195) voer aan dat wonderwerke viervoudige betekenis inhou, naamlik Jesus is almagtig en God; Hy is vol liefde en barmhartigheid; Hy verlos sondaars en bring 'n nuwe bedeling; en elke wonder wys vooruit na die volmaakte bedeling wat kom.

Venter (1983:83) voer aan dat die genesing van die blinde man in Betsaida (Mark. 8:22-26) as afsluiting van die eerste gedeelte van die Markusevangelie, maar ook as inleiding tot die tweede deel van die Evangelie dien. Die verband tussen die genesing van die blinde en die geestelike blindheid van die dissipels word aangetoon. Dit vorm die aanleiding tot die volle openbaring ten opsigte van Jesus se lyde en sy navolging. In die wonderwerke gaan dit om Jesus se selfopenbaring en die open van sy dissipels se oë. In Jesus se onderrig speel wonders 'n belangrike rol (Venter, 1983:83 e.v., 89). In die sentrale dissipelskapsgedeelte is daar minder wonders, terwyl die wonderwerke minder belangrik word namate die kruisgebeure nader kom, omdat Jesus se woordopenbaring die volle waarheid in duidelike taal verkondig (Venter, 1983:92).

Die openbaringshistoriese benadering neem as vertrekpunt dat God Homself in en deur 'n reeks historiese gebeure openbaar het. Die fokus val nie op die historiese gebeure as sodanig nie, maar op die boodskap wat deur die gebeure, in samehang met 'n reeks gebeure, geopenbaar word. Jesus se wonders in die Markusevangelie vorm deel van hierdie reeks Goddelike openbarings. 


\section{Gevolgtrekkings}

Uit die bespreking van navorsing oor die wonderverhale blyk dit dat elke benadering 'n bepaalde faset tot die debat toegevoeg het. Die hooftrekke van hierdie fasette word samevattend kortliks genoem.

Die mitologiese interpretasie van die wonderwerke is van mening dat 'n konsekwente historiese ondersoek die evangelie van sy waarde stroop. Wonders sou deel uitmaak van 'n uitgediende mitologiese wêreldbeeld. Hierdie benadering maak egter 'n onoortuigende skeiding tussen die wonderverhale en onderrig in die Evangelies. Die Bybelse teologiebenadering toon oortuigend aan dat wonderverhale ' $n$ integrale deel van die Evangelies vorm. Wonderverhale lig die onderrig van Jesus toe. Redaksiehistoriese navorsers toon die inherente plek van wonderverhale in die Evangelies aan, deurdat hulle bydra tot die geheelboodskap van die betrokke Evangelie. Die sosiologiese benadering ondersoek die sosiale konteks van die wonders en bepaal watter sosiale impak die wonders in die destydse samelewing sou gehad het. Die narratiewe benadering fokus op die funksie wat die wonderverhale in die geheel van die narratief speel. Van der Loos en Brown bepleit dat die band tussen die wonderverhale en die onderrig van Jesus gehandhaaf word. Die wonderverhale toon die Goddelike gesag waarmee Jesus kon leer en optree. Volgens die heilshistoriese benadering is die wonders nie 'n doel op sigself nie, maar ' $n$ wesenlike middel om die lesers tot geloof in Jesus as Here en Christus op te roep. Die openbaringshistoriese benadering fokus op die openbaring van God deur die wonderwerke, in samehang met 'n reeks gebeure van goddelike openbaring. Deur die wonderverhale openbaar God dat Jesus die verwagte Messias is.

Uit hierdie Forshungsbericht blyk dit dat die wonderverhale as 'n integrale deel van die Evangelies beskou moet word. Tussen Jesus se woord- en daadverkondiging kan onderskei word, maar dit kan nie geskei word nie. As Goddelike Leraar doen Jesus wonders. Die wonders illustreer dat Jesus die Verlosser is en dat die koninkryk van God gekom het. In sy groot ontferming reik Jesus na noodlydendes uit. Twee teenoorgestelde reaksies volg op Jesus se woorden daadverkondiging, naamlik geloof óf ongeloof. Die wonderwerke is ' $n$ vorm van Goddelike openbaring wat alleen in die geloof werklik verstaan kan word. In die wonderverhale word Jesus as die paradoksale Messias, Seun van die mens en die Seun van God geopenbaar. Jesus wat leer en wonders doen, is ook die lydende Seun van die mens. Hy word gekruisig, maar staan ook op uit die dood. Hy is 
mens, maar ook God. Die wonderverhale openbaar Jesus se Goddelike alvermoë.

\section{Geraadpleegde bronne}

BAL, M. 1985. Narratology: introduction to the Theory of Narrative. Toronto: University of Toronto Press.

BEST, E. 1981. Following Jesus: journal for the study of the New Testament. Sheffield: Journal for the Study of the New Testament. (JSOT Supplement Series, 4.)

BOLT, P.G. 2003. Jesus's defeat of death. Cambridge: Cambridge University Press. (Society for New Testament Studies, Monograph series, 125.)

BOUSSET, W. 1970. Kyrios Christos: a history of the belief in Christ from the beginnings of Christianity to Irenaeus. 2nd ed. Nashville: Abingdon.

BROADHEAD, E.K. 1992. Teaching with authority: miracles and Christology in the Gospel of Mark. Sheffield: Journal for the Study of the New Testament. (JSOT Supplement Series, 74.)

BROWN, C. 1984. Miracles and the critical mind. Grand Rapids: Eerdmans.

BULTMANN, R. 1961. Zur Frage des Wunder. (In Bultmann, R., red. Glauben und Verstehen: gesammelte Aufsätze. 1. Bd. Tübingen: Mohr. S. 214228.)

BULTMANN, R. 1965. Christus und die Mythologie. (In Bultmann, R., red. Glauben und Verstehen: gesammelte Aufsätze. 4. Bd. Tübingen: Mohr. S. 141-189.)

BULTMANN, R. 1979. Die Geschichte der synoptischen tradition. 2. Aufl. Göttingen: Vandenhoeck \& Ruprecht.

COETZEE, J.C. 1970. Die betekenis van kruis en opstanding by Rudolf Bultmann. Neotestamentica, 4:108-131.

DIBELIUS, M. 1934. From tradition to Gospel. New York: Scribner.

DULING, D.C. \& PERRIN, N. 1994. The New Testament: proclamation and parenesis, myth and history. Fort Worth: Harcourt Brace.

ENGELBRECHT, J. 1983. Die funksie van die wondervertellings in Markus. Pretoria: Unisa. (Ongepubliseerde proefskrif.)

FLOOR, L. 1981. Die evangelie van die koninkryk. Pretoria: NG Kerkboekhandel.

FLYNN, L.B. 1990. The miracles of Jesus. Wheaton: Victor.

HELBERG, J.L. 1976a. Openbaringsgeskiedenis van die Ou Testament. Vol. 1. Potchefstroom: Pro Rege.

HELBERG, J.L. 1976b. Ou Testamentiese teologie in verleentheid. Potchefstroom: $\mathrm{PU}$ vir $\mathrm{CHO}$.

KEE, H.C. 1977. Community of the New Age. London: SCM.

KEE, H.C. 1988. Medicine, miracle and magic in New Testament times. Cambridge: Cambridge University Press. (Society for New Testament Studies Monograph Series, no. 55.)

KERTELGE, K. 1995. The ephiphany of Jesus in the Gospel (Mark). (In Telford, W.R., ed. The interpretation of Mark. Edinburgh: Clark. p. 105-124.)

LATOURELLE, R. 1988. The miracles of Jesus and the theology of miracles. Mahwah: Paulist. 
MALBON, E.S. 1994. The major importance of the minor characters in Mark. (In Malbon, E.S. \& Mc Knight, E.V., eds. The new literary criticism and the New Testament. Sheffield: Sheffield Academic Press. p. 58-86.) (Journal for the Study of the New Testament Supplement, 109.)

MARSHALL, C.D. 1989. Faith as a theme in Mark's narrative. Cambridge: Cambridge University Press.

MEYE, R.P. 1968. Jesus and the twelve. Grand Rapids: Eerdmans.

MEYE, R.P. 1978. Psalm 107 as "horizon" for interpreting the miracle stories of Mark 4:35-8:26 (In Guelich, R.A., ed. Unity and diversity in New Testament theology: essays in honor of George E. Ladd. Grand Rapids: Eerdmans. p. 1-13.)

PERRIN, N. 1995. The Christology of Mark: a study in methodology. (In Telford, W.R., ed. The interpretation of Mark. Edinburgh: Clark. p. 125-140.)

RICHARDSON, A. 1948. The miracle-stories of the Gospels. London: SCM.

RIDDERBOS, H.N. 1968. De nieuwe discussie over de zogenaamde historische Jezus. (In Berkouwer, G.C., red. Het Woord, het rijk en onze verlegenheid. Kampen: Kok. p. 70-95.)

RIDDERBOS, H.N. 1972. De komst van het Koninkryk. Kampen: Kok.

SCHWEIZER, E. 1995. Mark's theological achievement. (In Telford, W.R., ed. The interpretation of Mark. Edinburgh: Clark. p. 63-87.)

SMALLEY, S.S. 1979. Redaction criticism. (In Marshall, I.H., ed. New Testament interpretation: essays on principles and methods. Exeter: Paternoster. p. 181-195.)

SNYMAN, W.J. 1977. Geskiedenis en heilsgeskiedenis by Bultmann. (In Snyman, P.C., red. Nuwe en ou dinge: uit die skat van die koninkryk. Potchefstroom: Pro Rege. p. 236-254.)

SNYMAN, W.J. \& FLOOR, L. 1969. Die koninkryk van God in die Nuwe Testament. (In du Toit, S., red. Die koninkryk van God. Potchefstroom: Potchefstroom Herald. p. 34-58.)

SNYMAN, W.J. \& FLOOR, L. 1977. Die koninkryk van God in die Nuwe Testament. (In Snyman, P.C., red. Nuwe en ou dinge: uit die skat van die koninkryk. Potchefstroom: Pro Rege. p. 195-224.)

STRAUSS, D.F. 1973 [1835]. The life of Jesus critically examined. London: SCM.

THEISSEN, G. 1983. The miracle stories of the early Christian tradition. Edinburgh: Clark.

UTH, D.F. 1991. An eschatological interpretation of the synoptic miracles in the mission and message of Jesus. Texas: Southwestern Baptist Theological Seminary. (Ph.D. dissertation.)

VAN DER LOOS, H. 1968. The miracles of Jesus. Leiden: Brill.

VAN DER WALT, T. 1962. Die koninkryk van God, naby! Eksegetiese verkennings van die toekomsperspektief van Jesus Christus volgens die getuienis van die sinoptiese Evangelies. Kampen: Theologische Hogeschool. ( D.Th.-proefskrif.)

VAN DER WALT, T. 2006. Die Messias het gekom. Potchefstroom: Potchefstroomse Teologiese Publikasies.

VAN WYK, J.H. 2002. Fundamentalisme en kritisisme: nadenke oor Skrifbeskouing en Skrifverklaring - van Augustinus tot Bultmann. In die Skriflig, 36(4):593-620.

VENTER, J.L. 1983. Jesus se wonders in Markus 8 binne die geheelstruktuur van die hoofstuk. Potchefstroom: PU vir CHO. (Th.M.-verhandeling.) 
VLEDDER, E.J. 1984. Die rol van "historisiteit" in die kommunikasie van die wondervertelling: 'n evaluering van twee eksegetiese benaderinge. Hervormde teologiese studies, 40(2):71-119.

VORSTER, W.S. 1980. Die Evangelie volgens Markus: inleiding en teologie. B. Die Teologie van Markus. (In Du Toit, A.B., red. Handleiding by die Nuwe Testament. Band 4: Die sinoptiese Evangelies en Handelinge: inleiding en teologie. Pretoria: NG Kerkboekhandel. p. 109-155.)

VORSTER, W.S. 1982. "Formgeschichte" en "Redaktionsgeschichte". (In Klijn, A.F.J., red. Inleiding tot de studie van het Nieuwe Testament. Kampen: Kok. p. 94-111).

WATTS, R.E. 1997. Isaiah's new Exodus in Mark. Grand Rapids: Baker.

WEEDEN, T.J. 1968. The heresy that necessitated Mark's gospel. Zeitschrift für die Neutestamentliche Wissenschaft, 59:145-158.

WEEDEN, T.J. 1971. Mark: traditions in conflict. Philadelphia: Fortress.

WILLIAMS, J.F. 1996. Discipleship and minor characters in Mark's Gospel. Bibliotheca sacra, 153:332-343.

WREDE, W. 1963. Das Messiasgeheimnis in den Evangelien: zugleich ein Beitrag zum Verständnis des Markusevangeliums. 3. Aufl. Göttingen: Vandenhoeck \& Ruprecht.

\section{Kernbegrippe:}

Christologie

daadverkondiging

interpretasie

koninkryk van God

wonderverhale

Key concepts:

Christology deed proclamation

interpretation

kingdom of God

miracle stories 